\title{
Bioactivities of Colocasia affinis Schott and Profiling of its Bioactive Polyphenols by HPLC-DAD
}

\author{
Shrabanti Dev ${ }^{1}$, Rabindra Nath Acharyya ${ }^{1}$, Manik Chandra Shill ${ }^{2}$, Md. Abdullah Al \\ Bari $^{1}$, Kaniz Asma ${ }^{1}$, Imran Mahmud ${ }^{1}$, Hemayet Hossain ${ }^{4}$, Nripendra Nath Biswas ${ }^{1}$, \\ Masum Shahriar ${ }^{3}$ and Asish Kumar Das ${ }^{1}$
}

\author{
${ }^{1}$ Pharmacy Discipline, Khulna University, Khulna-9208, Bangladesh. \\ ${ }^{2}$ Department of Pharmaceutical Sciences, North South University, Dhaka-1229, Bangladesh. \\ ${ }^{3}$ Department of Pharmacy, Jahangirnagar University, Savar, Dhaka. \\ ${ }^{4}$ BCSIR Laboratories, Bangladesh Council of Scientific and Industrial Research (BCSIR), Dhaka, Bangladesh.
}

(Received: November 16, 2020; Accepted: December 24, 2020; Published (Web): January 28, 2021)

\begin{abstract}
Traditional medicines including Ayurveda, Unani have been used as therapeutics in the Indian subcontinent since $5000 \mathrm{BC}$. Because of the abundance of secondary metabolites, medicinal plants are becoming priceless natural resources for better drug development. Till date almost no ethnopharmacological evidences were available on Colocasia genus except Colocasia esculenta. As a part of our continuing assessment of evidence based use of traditional medicine, we have identified bioactive polyphenols in the ethanolic leaves extract of Colocasia affinis Schott using HPLC-DAD method and evaluated its anti-allergy, anti-inflammatory and anti-diabetic potentials for the first time. Chromatographic investigation showed the presence of p-coumaric acid, trans-ferulic acid, rosmarinic acid, myricetin and kaempferol in the leaves extract. Pharmacological exploration demonstrated its anti-inflammatory activity at a dose of $250-$ and $500-\mathrm{mg} / \mathrm{kg}$ in xylene-induced ear edema in mice. The extract significantly reduced the allergy like symptoms such as sneezing, scratching, rhinorrhea, redness and swelling in Tolune diisocyanate (TDI) sensitized allergy model mice at $250-$ and $500-\mathrm{mg} / \mathrm{kg}$ doses. Besides, the extract also exhibited reduction in the level of neutrophils, lymphocytes and eosinophils in a dose dependent manner in the experimental animal. The extract also confirmed reduction of blood glucose levels in the experimental mice at a dose of 250 - and $500-\mathrm{mg} / \mathrm{kg}$. Therefore, it is evident that $C$. affinis demessestinal values through its anti-inflammatory, allergic and anti-hyperglycaemic potentials.
\end{abstract}

Key words: Colocasia affinis, allergy, inflammation, diabetes.

\section{Introduction}

Allergy is a hypersensitivity reaction instigated by specific immunologic mechanisms (Johansson, 2009). The incidence and prevalence of allergic diseases such as asthma and allergic rhinitis (AR) are rising worldwide, and the economic burden tends to be even higher. In allergic diseases, the inflammatory cells such as neutrophils, eosinophils and $\mathrm{T}$ cells as well as the activities of cytokines and chemokines are aggravated markedly (Arshad et al., 2012).

Again, Diabetes mellitus (DM) is one of the burning health issues, affecting 382 million people globally which account for 5.3 million deaths in 2013 (Danaei et al., 2011). Although previously it was thought that diabetes is a disease of the affluent, but now its prevalence is rising in low to middle income countries, particularly in South Asia DM is mediated by $\mathrm{T}$ helper 1 (Th1), whereas asthma and other atopic conditions are mainly predominant by $\mathrm{T}$ helper 2 (Th2) cell responses. Previous reports have pointed out the increased incidence of asthmatic symptoms in diabetic patients and the coexistence of Th1-Th2 diseases in the same individual (Duran et al., 2008). Therefore, compounds that ameliorate both Th1-Th2

Corresponding author: Asish Kumar Das; Email: dasasish03@yahoo.com

DOI: https://doi.org/10.3329/bpj.v24i1.51629 
diseases at the same time are more rational and cost effective.

Traditional medicines (TM) has been practiced worldwide for thousands of years and still remain as a good source of structurally important chemical substances that lead to the development of modern medicines (Jachak and Saklani, 2007). On the other hand, Ayurveda, a comprehensive and integral medicinal system, has been practiced in Indian subcontinent since 5000 BC (Mukherjee et al., 2010). Colocasia esculenta (L.) herb has been used for the various ailments such as asthma, arthritis, diarrhea, internal hemorrhage, neurological disorders, and skin disorders. The plant also possesses analgesic, antiinfammatory, anti-cancer, hypoglycemic and hypolipidemic effects (Temesgen and Retta, 2015). As a part of our ongoing exploration of evidence based usages of medicinal plants of Bangladesh, the present work was carried out to evaluate different pharmacological activities including the antiinflammatory, anti-allergic and anti-diabetic effects of the leaf extract of $C$. affinis. This plant is widely found in Chittagong hill tracts, on hill slopes in shade and rural villages of Bangladesh. C. affinis an herb belongs to Araceae family that usually grows to 1- 3 feet tall with leaves $10-15 \mathrm{~cm}$ long, ovate or orbicular-ovate, base rounded, green with dark blotches between the nerves. Spathe grows 10-15 cm long, tumid, green; limb primrose yellow. Spadix is narrow neck between the male and female inflorescence; appendage slender, narrowed to the tip, golden yellow. Leaf and petiole are cooked as vegetables and are reported to be effective to treat cataract (Pasha and Uddin, 2013). Although most of the people of Bangladesh use the plant as cooking food, some local people of Khulna and Chittagong report to use this plant for allergic complications, diabetes, hemorrhage and anemia. No pharmacological studies targeting allergy and diabetes were reported till today on $C$. affinis. Therefore, we studied anti-allergic, anti-inflammatory and anti-diabetic effects of this edible herb.

\section{Materials and Methods}

Plant collection and extraction: The leaves of $C$. affinis were collected from Satkhira region, Bangladesh and was authenticated by the medicinal plant expert of National Herbarium, Dhaka, Bangladesh. A voucher specimen no. 41234 has been preserved for further reference. The collected leave was separated from undesirable materials and shaded for 7-12 days followed by grinding into coarse powder with the help of a suitable grinder. About 420 gm of powered material was taken in a clean, flatbottomed glass container and soaked in $1200 \mathrm{ml}$ ethanol. The container with its contents was closed and kept for a period of 10 days accompanying with occasional shaking and stirring. The whole mixture then underwent a coarse filtration with cotton bed. The filtrate was then further filtered through Whatman filter paper and The filtrate (ethanol extracts) was dried using rotary evaporator at $40^{\circ} \mathrm{C}$. It rendered a gummy concentrate of greenish black color and was. The gummy concentrate was designated as crude ethanolic extract of $C$. affinis leaves for further experiments.

Experimental animal: Young Swiss-albino mice aged 5-6 weeks, average weight 20-28 gm were used for the experiment. They were kept under standard environmental condition for one week in the animal house of Pharmacy Discipline, Khulna University, Khulna- 9208, for adaptation after their purchase. The animals were provided with standard laboratory food and tap water and maintained at natural day light cycle. All the experiments on animal were conducted after the approval of Pharmacy Discipline, Khulna University Animal Ethics Committee (Approval no. KU/PHARM/AEC/15/006/024).

HPLC detection and quantification of polyphenolic compounds: Detection and quantification of selected phenolic compounds in the ethanol extract were determined by HPLC-DAD analysis (Jahan et al., 2014), with miner modifications. It was carried out on a Dionex UltiMate 3000 system equipped with quaternary rapid separation pump (LPG-3400RS) and photodiode array detector (DAD-3000RS). Separation was 
performed using Acclaim ${ }^{\circledR} \quad \mathrm{C}_{18} \quad(5 \mu \mathrm{m})$ Dionex column $(4.6 \times 250 \mathrm{~mm})$ at $30^{\circ} \mathrm{C}$ with a flow rate of 1 $\mathrm{ml} / \mathrm{min}$ and an injection volume of $20 \mu \mathrm{l}$. The mobile phase consisted of acetonitrile (solvent A), acetic acid solution pH 3.0 (solvent B), and methanol (solvent C) with the gradient elution program of $5 \% \mathrm{~A} / 95 \% \mathrm{~B}(0-5$ $\min ), \quad 10 \% \mathrm{~A} / 90 \% \mathrm{~B}$ (6-9), $15 \% \mathrm{~A} / 75 \% \mathrm{~B} / 10 \% \mathrm{C}$ (1115), $20 \% \mathrm{~A} / 65 \% \mathrm{~B} / 15 \% \mathrm{C}(16-19 \mathrm{~min}), 30 \% \mathrm{~A} / 50 \% \mathrm{~B} /$ 20\%C (20-29 min), 40\%A/30\%B/30\%C (30-35) and $100 \%$ A (36-40 min). The UV detector was set to 280 $\mathrm{nm}$ for $22.0 \mathrm{~min}$, changed to $320 \mathrm{~nm}$ for $28.0 \mathrm{~min}$, again change to $280 \mathrm{~nm}$ for $35 \mathrm{~min}$ and finally to 380 $\mathrm{nm}$ for $36 \mathrm{~min}$ and held for the rest of the analysis period while the diode array detector was set at an acquisition range from $200 \mathrm{~nm}$ to $700 \mathrm{~nm}$. For the preparation of calibration curve, a standard stock solution was prepared in methanol containing arbutin (AR), (-)-epicatechin (ECA) $(5 \mu \mathrm{g} / \mathrm{ml}$ each), gallic acid (GA), hydroquinone (HQ), vanillic acid (VA), rosmarinic acid (RA), myricetin (MC) (4 $\mu \mathrm{g} / \mathrm{ml}$ each), caffeic acid (CA), Syringic acid (SA), vanillin (VL), trans-ferulic acid (FA) (3 $\mu \mathrm{g} / \mathrm{ml}$ each), $p$ coumaric acid (PCA), quercetin (QU), kaempferol (KF) $(2 \mu \mathrm{g} / \mathrm{ml}$ each), (+)-catechin hydrate $(\mathrm{CH})$, ellagic acid (EA) $(10 \mu \mathrm{g} / \mathrm{ml}$ each), trans-cinnamic acid (TCA) $(1 \mu \mathrm{g} / \mathrm{ml})$, rutin hydrate (RH) $(6 \mu \mathrm{g} / \mathrm{ml})$ and benzoic acid (BA) $(8 \mu \mathrm{g} / \mathrm{ml})$. A solution of the extract was prepared in ethanol having the concentration of $10 \mathrm{mg} / \mathrm{ml}$. Prior to HPLC analysis, all the solutions (mixed standards, sample, and spiked solutions) were filtered through $0.20 \mu \mathrm{m}$ syringe filter (Sartorius, Germany) and then degassed in an ultrasonic bath (Hwashin, Korea) for $15 \mathrm{~min}$. Data acquisition, peak integration, and calibrations were calculated with Dionex Chromeleon software (Version 6.80 RS 10).

Evaluation of anti-allergic activity of C. affinis: This test was carried out as per the procedure previously described (Dev et al., 2009) with slight modifications. Thirty experimental animals were randomly selected and divided into five groups consisting of six mice in each group. Group-I (negative control) received ethyl acetate $(10 \mu 1)$ bilaterally in the nasal vestibules and 2\% tween 80 water orally. Group-II served as positive control and was given TDI $(10 \mu 1$ of $5 \%$ TDI solution in ethyl acetate) bilaterally in the nasal vestibules and $2 \%$ tween-80 water equivalent to the vehicle given with the extract. Group-III served as standard group and was given TDI $(10 \mu 1$ of $5 \%$ TDI solution in ethyl acetate) bilaterally in the nasal vestibules and Cetirizine $20 \mathrm{mg} / \mathrm{kg}$ body weight orally. Group-IV and group-V received ethanolic extract of $C$. affinis leaves $(250 \mathrm{mg} / \mathrm{kg}$ and $500 \mathrm{mg} / \mathrm{kg}$ body weight respectively) and TDI (10 $\mu 1$ of $5 \%$ TDI solution in ethyl acetate) bilaterally in the nasal vestibules.

TDI sensitization and provocation: $10 \mu \mathrm{l}$ of a $5 \%$ solution of TDI in ethyl acetate was applied bilaterally on the nasal vestibule of each mouse once a day for five consecutive days. This sensitization procedure was then repeated after a 2-day interval. Nine days after the second sensitization, $10 \mu \mathrm{l}$ of $10 \%$ TDI solution was again applied to the nasal vestibule to provoke nasal allergy-like symptoms. The control group was sensitized and provoked with $10 \mu \mathrm{l}$ of ethyl acetate only by the same procedure. Group-IV and group-V received ethanolic extract of $C$. affinis leaves once a day throughout experiment. The extract was administered $1 \mathrm{~h}$ before TDI application. GroupIII received cetirizine at a dose of $20 \mathrm{mg} / \mathrm{kg}$ body weight on $21^{\text {st }}$ day just $1 \mathrm{hr}$ before TDI provocation. Schematic diagram of the experimental protocol is depicted in Figure 1.

Evaluation of nasal allergic-like symptom: Nasal allergy-like symptoms were measured during $10 \mathrm{~min}$ just after TDI provocation. It includes the number of sneezes, number of scratch and the nasal score, including the extent of watery rhinorrhea, swelling, and redness, measured on a scale ranging from zero to three (Table 1).

Differential analysis of blood: After $24 \mathrm{hr}$ of provocation, each mouse was sacrificed and blood was collected from the jugular vein. For differential analysis, blood slides were prepared and stained with Leishman reagent. After drying, slides were examined under microscope and cells were identified and counted as neutrophils, lymphocytes, eosinophils, monocytes and basophils. 


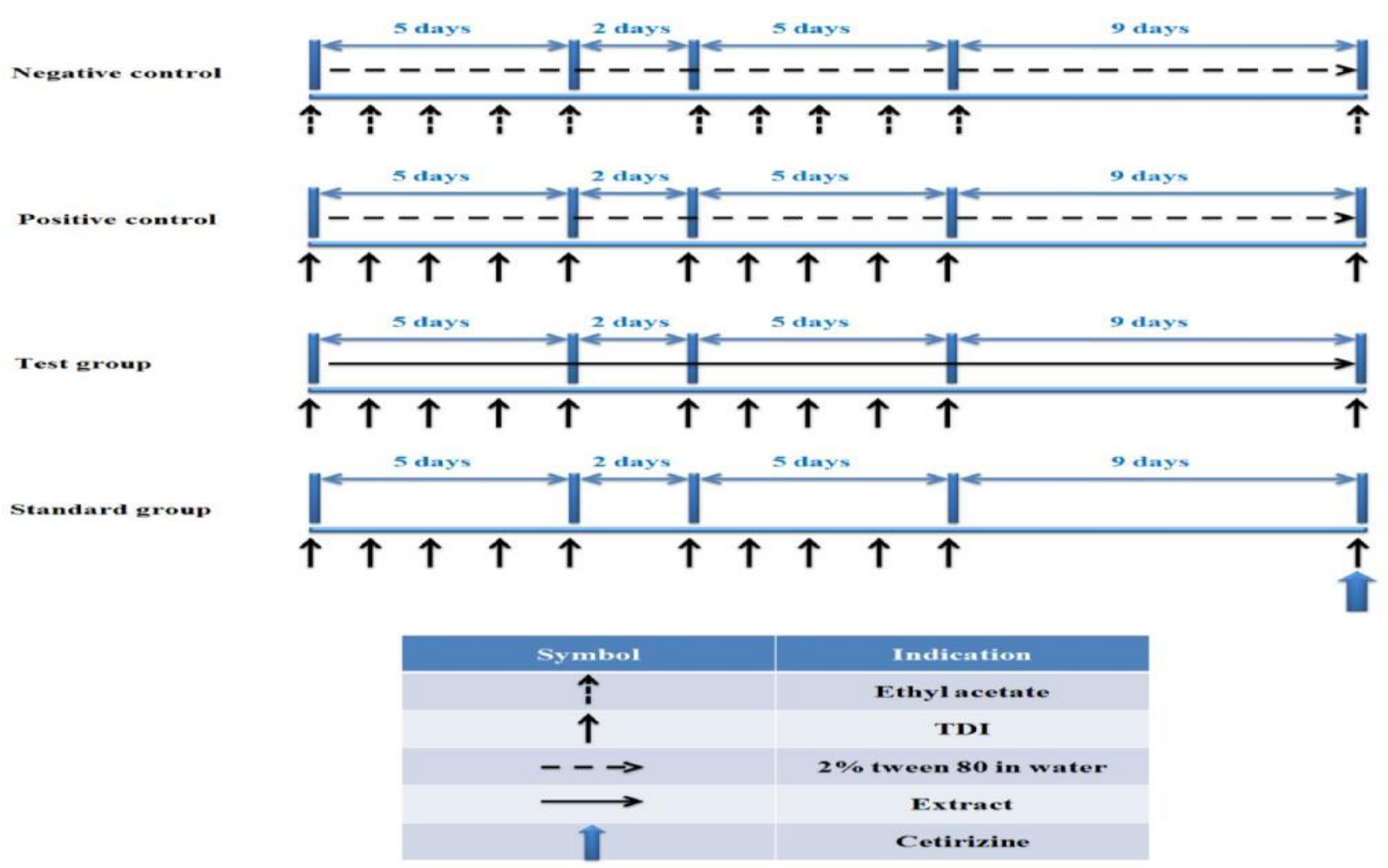

Figure 1. Experimental protocol for the assessment of allergy-like symptoms of $C$. affinis leaves extract on experimental mice.

Table 1. Criteria for grading the severity of TDI-induced nasal responses in allergic model mice.

\begin{tabular}{lcccc}
\hline Allergic symptoms & \multicolumn{3}{c}{ Score } \\
\hline Nasal response & 0 & 1 & 2 & 3 \\
Watery rhinorria & $(-)$ & At the nostril & Between 1 and 3 & Drops of discharges \\
Swelling and redness & $(-)$ & Slightly swollen & Between 1 and 3 & Strong swelling with redness \\
\hline
\end{tabular}

\section{Evaluation of Anti-inflammatory activity}

Xylene-induced ear edema model: In this study the male Swiss-albino mice were randomly divided into four groups with six mice in each group. Group-I or the control group received only vehicle (2\% Tween 80 in water, $0.5 \mathrm{ml}$ each mice), Group-II or the positive control group received standard drug Diclofenac Sodium at a dose of $10 \mathrm{mg} / \mathrm{kg}$ body weight and the test groups (Group III and IV) were treated with suspension of extracts of $C$. affinis at two different doses $(250$ and $500 \mathrm{mg} / \mathrm{kg}$ ). After one hour of oral administration of the extracts, Xylene $(0.01$ $\mathrm{ml}$ ) was applied to the anterior and posterior surfaces of the right ear of each mouse. Mice were sacrificed 1 hr. after xylene application and both ears were removed. Circular sections of both treated and untreated ears were taken using a $7 \mathrm{~mm}$ diameter cork borer and weighed. The difference in weight between left untreated ear section and right treated ear section were calculated.

Anti-diabetic activity of $C$. affinis: Oral glucose tolerance test was carried out as per the procedure previously described (Ilham, Ali, Hasan, Kaisar, and Bachar, 2012). Twenty experimental animals were randomly selected and divided into four groups denoted as group-I, group-II, group-III, group-IV 
consisting of six mice in each group. Group-I received ( $2 \%$ Tween 80 in water, $0.5 \mathrm{ml}$ each mice), termed as control group. Group-II received Glibenclamide at a dose of $10 \mathrm{mg} / \mathrm{kg}$ body weight and termed as standard group. Group-III to IV received the ethanolic extract of leaves of $C$. affinis at dose of $250 \mathrm{mg} / \mathrm{kg}$ body weight $500 \mathrm{mg} / \mathrm{kg}$ body weight and termed as test-I and test-II group respectively.

To perform the glucose tolerance test (Joy and Kuttan, 1999), mice were kept fasting overnight. Fasting blood glucose level of each mouse was measured using glucometer (Gluco Leader, HQS-
GLM-77, manufactured by HMD BioMedical Inc.). Blood sample was collected by cutting the tail tips with a sharp blade. The extracts, standard and control samples were given orally to the respective mice with the help of feeding needle. All the groups were administered $(2 \mathrm{~g} / \mathrm{kg}$ body weight) glucose solution orally 30 minutes after receiving the drug/extract. Blood glucose levels were measured at 30 minutes, 90 minutes and 150 minutes after glucose administration (Joy and Kuttan, 1999). Protocol has been designed in Figure 2.

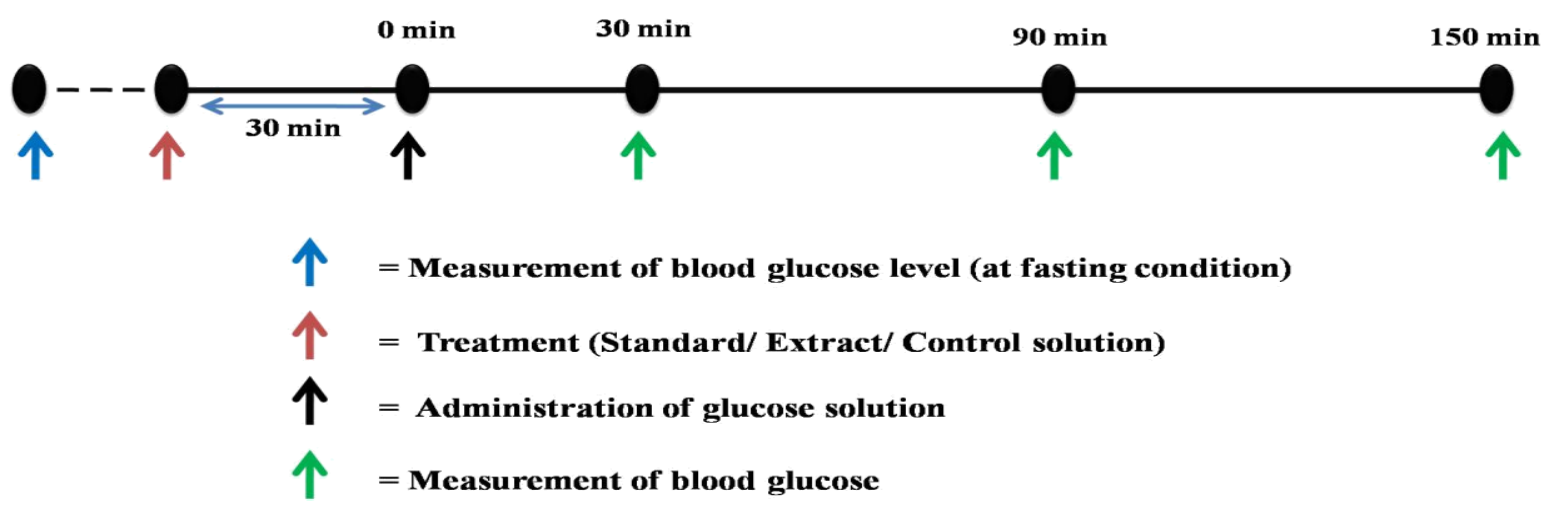

Figure 2. Experimental protocol of glucose tolerance test for measuring anti-diabetic effects of $C$. affinis leaves extract on experimental mice.

\section{Results and Discussion}

Assessment of phenolic contents of C. affinis leaf extract: According to our newly developed HPLC method, we have analysed nineteen known polyphenolic compounds simultaneously with high level of precision. This HPLC procedure provided excellent identification and quantification of the phenolic compounds present in $C$. affinis leaf extract within a short analysis time (40 min). HPLC chromatogram as shown in Figure 4 confirmed the presence of $p$-coumaric acid (PCA), trans-ferulic acid (FA), rosmarinic acid (RA), myricetin (MC) and kaempferol $(\mathrm{KF})$ and their respective quantification is summarized in the Table 2.
Assessment of allergy-like symptoms of C. affinis leaves extract: Intranasal application of TDI-induced nasal allergy like symptoms include sneezing, watery rhinorrhea, redness, swelling and itching (scratch). In TDI-sensitized mice, the total number of sneezes, scratches and the nasal score were $35 \pm 4.52$, $231.7 \pm 5.31$ and $3 \pm 0$ respectively (Table 3 ). Oral administration of ethanolic extract of $C$. affinis leaves significantly decreased allergic symptoms (sneezes, scratch and the nasal score) in a dose dependent manner. The efficacy of the $C$. affinis extract at a dose of $500 \mathrm{mg} / \mathrm{kg}$ was comparable with that of antihistamine Cetirizine $20 \mathrm{mg} / \mathrm{kg}$ dose (Table 3 ). 


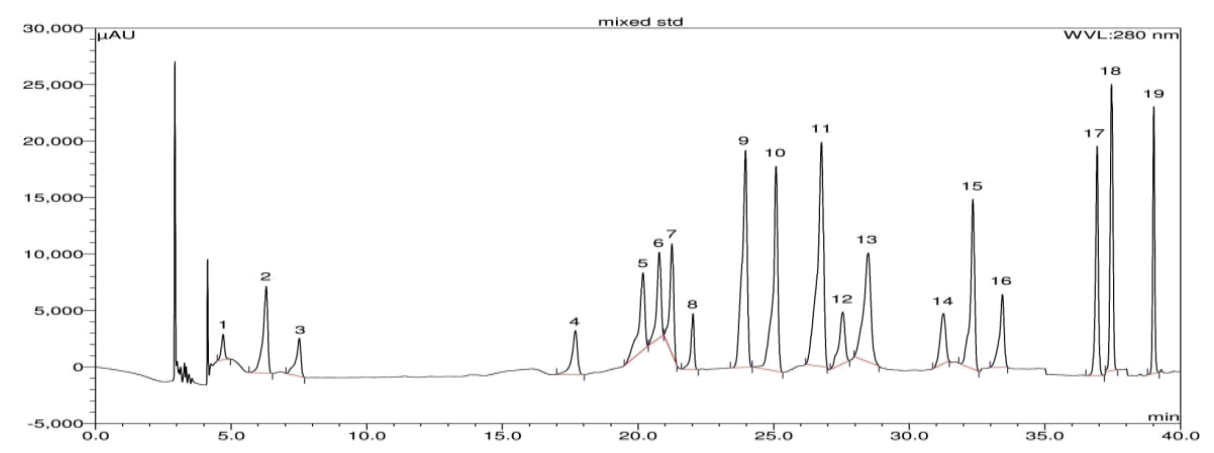

Figure 3. HPLC chromatogram of a standard mixture of polyphenolic compounds. Peaks: 1, arbutin; 2, gallic acid; 3, hydroquinone; 4, (+)-catechin; 5, vanillic acid; 6 , caffeic acid; 7, syringic acid; 8, (-)-epicatechin; 9, vanillin; 10, $p$ coumaric acid; 11, trans-ferulic acid; 12, rutin hydrate; 13, ellagic acid; 14, benzoic acid; 15, rosmarinic acid; 16 , myricetin; 17, quercetin; 18, trans-cinnamic acid; 19, kaempferol.

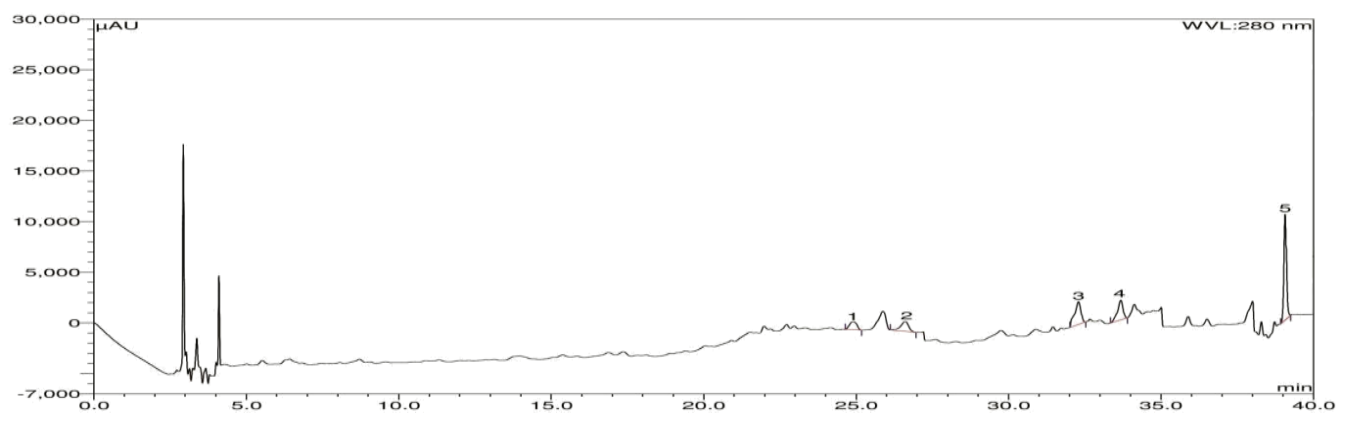

Figure 4. HPLC chromatogram of ethanol extract of $C$. affinis leaf extract. Peaks: 1, p-coumaric acid (PCA); 2, trans-ferulic acid (FA); 3, rosmarinic acid (RA); 4, myricetin (MC); 5, kaempferol (KF).

Table 2. Contents of polyphenolic compounds in ethanolic extract of leaves of C. affinis.

\begin{tabular}{lcc}
\hline Polyphenolic compound & Content $(\mathrm{mg} / 100 \mathrm{~g}$ of dry extract $)$ & $\%$ RSD \\
\hline PCA & 15.03 & 0.21 \\
\hline FA & 10.22 & 0.16 \\
\hline RA & 18.64 & 0.29 \\
\hline MC & 29.81 & 0.58 \\
\hline KF & 47.22 & 1.03
\end{tabular}

PCA: p-coumaric acid, FA: trans-ferulic acid, RA: rosmarinic acid, MC: myricetin and KF: kaempferol; RSD: Relative Standard Deviation

Table 3. Assessment of the allergy-like symptoms of $C$. affinis leaves extract in mice.

\begin{tabular}{lccc}
\hline \multicolumn{1}{c}{ Group } & No. of sneezes & No. of Scratch & Nasal score \\
\hline Negative Control & $0.33 \pm 0.33$ & $12.3 \pm 0.88$ & 0 \\
(2\% Tween in water, 0.5 mL in each mice) & & & $3 \pm 0 *$ \\
Positive control (5\% TDI) & $35 \pm 4.52^{*}$ & $231.7 \pm 5.31^{*}$ & $0.4 \pm 0.24^{* *}$ \\
Standard Cetirizine $(20 \mathrm{mg} / \mathrm{kg})$ & $9.4 \pm 2.56^{* *}$ & $136.4 \pm 14.14^{* *}$ & $1.2 \pm 0.2^{* *}$ \\
Test-I ( EECA 250 mg/kg) & $22.4 \pm 1.44^{* *}$ & $206.2 \pm 9.97 * *$ & $0.4 \pm 0.24^{* *}$ \\
Test-II (EECA 500 mg/kg) & $14.6 \pm 1.50^{* *}$ & $104.6 \pm 11.01^{* *}$ & \\
\hline
\end{tabular}

Values are expressed as mean $\pm \operatorname{SEM}(n=6)$. $* \mathrm{p}<0.05$ vs. control and $* * \mathrm{p}<0.05$ vs. TDI (positive control). EECA= Ethanolic extract of Colocasia affinis. 
Table 4. Effects of $C$. affinis leaves extract on total and differential counts of blood.

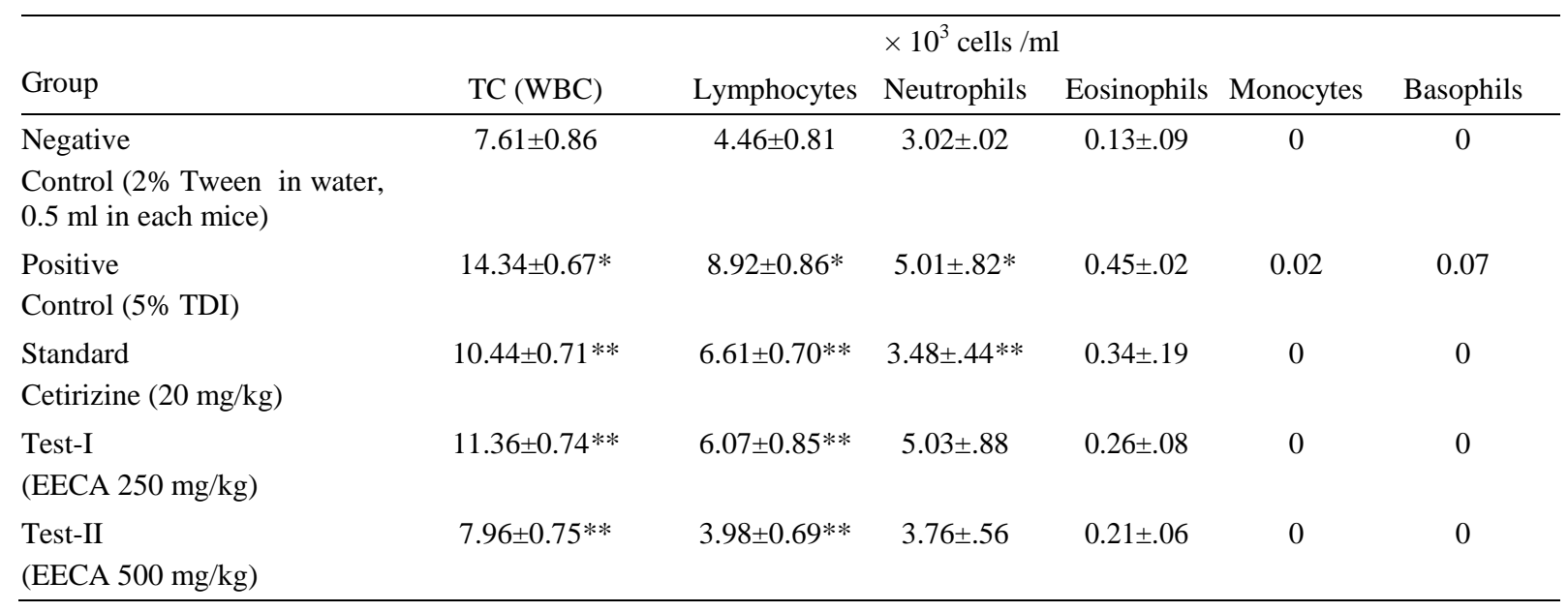

Effects of C. affinis leave extract on total and differential counts of blood: The differential analysis of blood revealed that oral administration of ethanolic extract of $C$. affinis leaves significantly decreased the total count of WBC and the number of neutrophils, lymphocytes and eosinophils in a dose dependent fashion when compared with positive control group. C. affinis leaves extract brought total WBC count in the basal level at a dose of $500 \mathrm{mg} / \mathrm{kg}$ which was even better than antihistamine cetirizine (Table 4). Moreover, C. affinis leaves extract significantly reduced the level of neutrophils, lymphocytes and eosinophils which can be comparable to cetirizine.

Anti-inflammatory effect of alcoholic extract of C. affinis: In xylene-induced ear edema model mice, the inhibitory effect of ethanolic extract of $C$. affinis extract was $14.18 \%$ and $23.37 \%(\mathrm{p}<0.05)$ at the doses of $250 \mathrm{mg} / \mathrm{kg}$ and $500 \mathrm{mg} / \mathrm{kg}$ body weight respectively indicating a significant lowering of xylene-induced ear edema in experimental mice at a dose of $500 \mathrm{mg} / \mathrm{kg}$ (Table 5).

Table 5. Anti-inflammatory effects of alcoholic extract of $C$. affinis on xylene-induced ear edema model mice.

\begin{tabular}{lcc}
\hline Group & Increased weight $(\mathrm{mg})$ & \% inhibition \\
\hline Control (2 \% Tween 80 in water, $0.5 \mathrm{ml}$ each mice) & $12.83 \pm 1.05$ & - \\
\hline Standard Diclofenac sodium $(10 \mathrm{mg} / \mathrm{kg})$ & $6 \pm 1.32 * *$ & 53.25 \\
\hline Test-I (EECA $250 \mathrm{mg} / \mathrm{kg})$ & $11 \pm 1.10$ & 14.29 \\
\hline Test-II (EECA $500 \mathrm{mg} / \mathrm{kg})$ & $9.83 \pm 0.60 *$ & 23.38 \\
\hline
\end{tabular}

Values expressed as mean $\pm \mathrm{SEM},(\mathrm{n}=6) ;{ }^{*} \mathrm{p}<0.05, * * \mathrm{p}<0.01$, compared to control. EECA= Ethanolic extract of Colocasia affinis.

Table 6. Hypoglycemic activity of ethanolic extract $C$. affinis leaves on experimental model mice.

\begin{tabular}{lcccc}
\hline \multirow{2}{*}{ Group } & \multicolumn{3}{c}{ Blood glucose level (mmol / L) } \\
\cline { 2 - 5 } & Fasting state & 30 min & 90 min & 150 min \\
\hline Control (2\% Tween 80 in water, 0.5 ml each mice) & $3.58 \pm 0.32$ & $11.42 \pm 0.35$ & $7.82 \pm 0.32$ & $6.1 \pm 0.32$ \\
\hline Standard Glibenclamide $(10 \mathrm{mg} / \mathrm{kg})$ & $3.78 \pm 0.39$ & $2.62 \pm 0.24^{*}$ & $2.90 \pm 0.26^{*}$ & $3.18 \pm 0.29^{*}$ \\
\hline Test-I (EECA $250 \mathrm{mg} / \mathrm{kg})$ & $3.72 \pm 0.32$ & $9.86 \pm 0.41^{*}$ & $7.0 \pm 0.34^{*}$ & $5.32 \pm 0.31^{*}$ \\
\hline Test- II (EECA $500 \mathrm{mg} / \mathrm{kg})$ & $3.46 \pm 0.24$ & $9.10 \pm 0.38^{*}$ & $6.64 \pm 0.29 *$ & $4.72 \pm 0.30^{*}$ \\
\hline
\end{tabular}

Values are expressed as mean \pm SEM $(n=6)$. $\mathrm{P}<0.05$ vs. control. EECA= Ethanolic extract of Colocasia affinis. 
Hypoglycemic activity of C. affinis leaves extract: Oral administration of $C$. affinis leaves extract to glucose-loaded mice at doses of 250 and $500 \mathrm{mg} / \mathrm{kg}$ body weight led to dose-dependent reductions in blood glucose levels compared to control mice (Table 6). The $C$. affinis leaves extract showed $4.72 \mathrm{mmol} / \mathrm{tL}$ blood glucose levels after 150 minutes at $500 \mathrm{mg} / \mathrm{kg}$ dose which can be comparable with that of $3.18 \mathrm{mmol} / \mathrm{LL}$ exhibited by standard drug (Table 6).

\section{Discussion}

Allergy is the hypersensitivity or hyperactivity of the immune system towards undefined foreign objects. Toluene 2,4-diisocyanate (TDI) is one of the leading causes of occupational allergic diseases in industrialized countries in mice (Abe et al., 1992). Intranasal application of TDI led to the development of nasal allergy-like symptoms such as sneezing and watery rhinorrhea (Kitamura et al., 2006). Studies have showed that TDI sensitization induces respiratory allergy with the activation of eosinophils, neutrophil and mast cells, and airway remodelling. Therefore, alleviation of TDI-induced allergic symptoms seemed to be an effective tool for evaluating allergic symptoms. In the present study, we found significant development of allergic symptoms and elevation of the circulating eosinophil and neutrophil count after TDI-provocation which was normalized by the ingestion of alcoholic extract of $C$. affinis (Tables 3 and 4). Again, ethanolic extract of $C$. affinis demonstrated a significant improvement of xylene-induced ear edema in experimental mice at a dose of $500 \mathrm{mg} / \mathrm{kg}$ (Table 5). The extracts also showed significant reduction on blood glucose level in different tested hours in oral glucose tolerance test (Table 6)

HPLC data demonstrated that alcoholic extract of C. affinis leaves is rich with flavonoids containing highest amount of kaempferol $(47.22 \mathrm{mg} /$ $100 \mathrm{~g}$ dry extract) followed by myricetin $(29.81 \mathrm{mg} /$ $100 \mathrm{~g}$ dry extract), rosmarinic acid $(18.64 \mathrm{mg} / 100 \mathrm{~g}$ dry extract), $p$-coumaric acid $(15.03 \mathrm{mg} / 100 \mathrm{~g}$ dry extract) and trans-ferulic acid $(10.22 \mathrm{mg} / 100 \mathrm{~g}$ dry extract) (Table 2). Previous studies have articulated the anti-allergic and anti-inflammatory effects of kaempferol (Kim et al., 2015), myricetin (Medeiros 2008), rosmarinic acid (Stansbury, 2014) and $p$ coumaric acid (Zhao et al., 2016). It has been demonstrated that kaempferol suppressed eosinophils infiltration and airway thickening along with inflammation in airway epithelial cells in experimental asthmatic models mice (Shin et al., 2015). In the present study, alcoholic extract of $C$. affinis illustrated normalization of anti-allergic symptoms, circulating eosinophils and neutrophils in the TDI model mice which seemed due to the presence of high amount of kaempferol in the plant extract. Moreover, myricetin and rosmerinic acid exhibited anti-allergic effects including suppression of interleukins that helps remodelling of asthma inflammation and exacerbations in model animals (Cho et al., 2007). All together it can be predicted that anti-inflammatory and anti-allergic activities of C. affinis leaves extract is the resultant of the additive or synergetic effect of flavonoids notably kaempferol, myricetin and rosmerinic acid present in the extract.

On the other hand, diabetes is no longer a disease of affluent rather its prevalence is raising in low to middle income countries predominantly in South Asia. Present study elucidated the anti-diabetic potential of the leaves extract of $C$. affinis. Earlier studies have demonstrated the proven potential of anti-diabetic effects of myricetin, $p$-coumaric acid, rosmarinic acid and ferulic acid (Runtuwene et al., 2016). HPLC data showed that $C$. affinis extract contain good amount of myricetin, $p$-coumaric acid, rosmarinic acid and trans-ferulic acid (Table 2). Hence, it can be speculated that the anti-diabetic effect of the leaves extract of $C$. affinis is may be due to the abundance of flavonoids.

Pivotal role of eosinophils and neutrophils in allergy, inflammation and asthma has is well established. This study also provide scientific evidence of anti-allergic and anti-inflammatory activities of $C$. affinis leaves for the first time ever 
documented which will promote its medicinal use in Bangladesh, South Asia and others.

Again, a positive correlation between eosinophil count and diabetic complication in men with Type 2 diabetes is also documented. It is also recognized that allergic disorders may be coupled with microalbuminuria in type 2 diabetic patients (Fukui et al., 2009). Furthermore, increased WBC count is linked to impaired glucose intolerance and various components of the metabolic syndrome. It is fascinating that both acute and chronic diabetic complications are correlated with elevated WBC count. Increased WBC count, is associated with both macro- and micro- vascular complications in type 2 diabetes (Tong et al., 2004). Present study provided data for anti-allergic and anti-diabetic activities of $C$. affinis leaves where it attenuated eosinophilia, neutrophilia, total WBC level and glucose tolerance. Consequently it can be evident that flavonoids present in the $C$. affinis leaves extract are the key players for anti-allergic and anti-diabetic activities.

\section{Conclusion}

Our study is the first scientific evidence for any pharmacological activities ever documented on $C$. affinis leaves. It is a good source of flavonoids which and they are effective against allergy, inflammation and diabetes. This study will vibrate other natural product researchers to work more on this plant. Our future direction is to isolate active compound(s) from this plant extract and develop suitable drugs for allergy, asthma and diabetes.

\section{Conflict of interest}

Authors declared no conflicts of interest.

\section{Funding}

We are grateful to Ministry of Science and Technology, The People's Republic of Bangladesh for funding to carry out this study [project no. 39.009.006.01.00.049.2013-2014/BS-92/92/1(4)].

\section{Acknowledgements}

The authors are grateful to the Department of Pharmacy, Jahangirnagar University, Bangladesh for providing experimental mice. The authors would like to express cordial thanks and regards to Chemical Research Division BCSIR Laboratories for conducting HPLC analysis.

\section{References}

Abe, Y., Takeda, N., Irifune, M., Ogino, S., Kalubi, B., Imamura, I., Matsunaga, T. 1992. Effects of capsaicin desensitization on nasal allergy-like symptoms and histamine release in the nose induced by toluene diisocyanate in guinea pigs. Actaoto. Laryngol. 112, 703-709.

Arshad, S.H., Dharmage, S.C., Ferreira, F., Fixman, E.D., Gadermaier, G., Hauser, M., Wardlaw, A.J. 2012. Developments in the field of allergy in 2011 through the eyes of Clinical and Experimental Allergy. Clin. Experi. Allergy. 42, 1697-1723.

Cho, Y-C, Yoon, G, Lee, K.Y., Choi, H.J., and Kang, B.Y. 2007. Inhibition of interleukin-2 production by myricetin in mouse EL-4 T cells. Arch. Pharmacal. Res. 30, 1075-1079.

Daniel, G., Finucane, M.M., Singh, G.M., Cowan, M.J., Paciorek, C.J., Lin, J.K., Farzadfar, F., Khang, Y-H., Stevens, G.A., Rao, M., Ali, M.K., Riley, L.M., Robinson, C.A. and Ezzati, M. 2011. National, regional, and global trends in fasting plasma glucose and diabetes prevalence since 1980: systematic analysis of health examination surveys and epidemiological studies with 370 country-years and 2 . 7 million participants. Lancet. 378, 31-40.

Dev, S., Mizuguchi, H., Das, A.K., Maeyama, K., Horinaga, S., Kato, S., Tamada, M., Hattori, M., Umehara, H. and Fukui, H. 2009. Kujin suppresses histamine signaling at the transcriptional level in toluene 2, 4-diisocyanate-sensitized rats. $J$. Pharmacol. Sci. 109, 606-617.

Duran, C., Ediger, D., Ersoy, C., Coskun, N.F., Selimoglu, H., Ercan, I. and Erturk, E. 2008. Frequency of atopy and allergic disorders among adults with Type 1 diabetes mellitus in the southern Marmara region of Turkey. J. Endocrinol. Investig. 31, 211-215.

Fukui, M., Tanaka, M., Hamaguchi, M., Senmaru, T., Sakabe, K., Shiraishi, E., Harusato, I., Yamazaki, M., Hasegawa, G. and Nakamura, N. 2009. Eosinophil count is positively correlated with albumin excretion rate in men with type 2 diabetes. Clin. J. Am. Soci. Nephrol. 4, 1761-1765. 
Ilham, S., Ali, M.S., Hasan, C.M., Kaisar, M.A. and Bachar, S.C. 2012. Antinociceptive and hypoglycemic activity of methanolic extract of Phlogacanthus thyrsiflorus Nees. Asian J. Pharma. Clin. Res. 5(2), 15-18.

Jachak, S.M. and Saklani, A. 2007. Challenges and opportunities in drug discovery from plants. Curr. Sci. 92(9), 1251 - 1257.

Jahan, I.A., Akbar, P.N., Khan, N., Khan, T.A., Rahman, M.M., Hira, A. and Hossain, H. 2014. Comparative study of anti-nociceptive activity and phenolic content of the ethanol extracts of Piper nigrum and Piper longum fruits. Int. J. Pharm. Sci. Rev. Res. 27, 47-52.

Johansson, S.G.O. 2009. New nomenclature and clinical aspects of allergic diseases. Frontiers. 31, 42.

Joy, K.L. and Kuttan, R. 1999. Anti-diabetic activity of Picrorrhiza kurroa extract. J. Ethnopharmacol. 67, 143-148.

Kim, S.H., Park, J.G., Lee, J., Yang, W.S., Park, W.W., Kim, H.G., Yi, Y-S., Baek, K-S., Sung, N.Y., Hossen, M.J., Lee, M-N., Kim, J-H. and Cho, J.Y. 2015. The dietary flavonoid Kaempferol mediates anti-inflammatory responses via the Src, Syk, IRAK1, and IRAK4 molecular targets. Mediat. Inflamm. 2015, $9041421-15$.

Kitamura, Y., Das, A.K., Murata, Y., Maeyama, K., Dev, S., Wakayama, Y., Kalubi, B., Takeda, N. and Fukui, H. 2006. Dexamethasone suppresses histamine synthesis by repressing both transcription and activity of HDC in allergic rats. Allergol. Int. 55, 279-286.

Kou, J., Ni, Y., Li, N., Wang, J., Liu, L. and Jiang, Z-H. 2005. Analgesic and anti-inflammatory activities of total extract and individual fractions of Chinese medicinal ants Polyrhachis lamellidens. Biolog. Pharma. Bullet. 28, 176-180.

Medeiros, K.C.P., Figueiredo, C.A.V., Figueredo, T.B., Freire, K.R.L., Santos, F.A.R., Alcântara, N., Neuza, M. and Piuvezam, M.R. 2008. Anti-allergic effect of bee pollen phenolic extract and myricetin in ovalbumin-sensitized mice. J. Ethnopharmacol. 119, 41-46.

Mukherjee, P.K., Venkatesh, P. and Ponnusankar, S. 2010. Ethnopharmacology and integrative medicine-let the history tell the future. J. Ayur. Integ. Med. 1, 100.

Pasha, M.K. and Uddin, S.B. 2013. Dictionary of plant names of Bangladesh (vascular plants). Janokalyan Prokashani. Chittagong, Dhaka, Bangladesh.p. 434.

Runtuwene, J., Cheng, K-C., Asakawa , A., Amitani, H., Amitani, M., Akinori Morinaga, A., Takimoto, Y., Kairupan, B.H.R. and Inui, A. 2016. Rosmarinic acid ameliorates hyperglycemia and insulin sensitivity in diabetic rats, potentially by modulating the expression of PEPCK and GLUT4. Drug Devel. Therapy. 10, 2193.

Shin, D., Park, S-H., Choi, Y-J., Kim, Y-H., Antika, L.D., Habibah, N.U., Kang, M-K. and Kang, Y-H. 2015. Dietary compound kaempferol inhibits airway thickening induced by allergic reaction in a bovine serum albumin-induced model of asthma. Int. J. Mol. Sci. 16, 29980-29995.

Stansbury, J. 2014. Rosmarinic acid as, novel agent in the treatment of allergies and asthma. J. Restor. Med. 3, 121-126.

Temesgen, M. and Retta, N. 2015. Nutritional potential, health and food security benefits of taro Colocasia esculenta (L.): a review. Food Sci. Qua. Manag. 36, 23-30.

Tong, P.C., Lee, K-F., So, W-Y., Ng, M.H., Chan, W-B., Lo, M.K., Chan and J.C. 2004. White blood cell count is associated with macro-and microvascular complications in Chinese patients with type 2 diabetes. Diabet. care. 27, 216-222.

Zhao, Y., Liu, J., Liu, C., Zeng, X., Li, X. and Zhao, J. 2016. Anti-inflammatory effects of p-coumaric acid in LPS-stimulated RAW264. 7 cells: Involvement of NF$\kappa \mathrm{B}$ and MAPKs pathways. J. Med. Chem. 6, 327-330. 